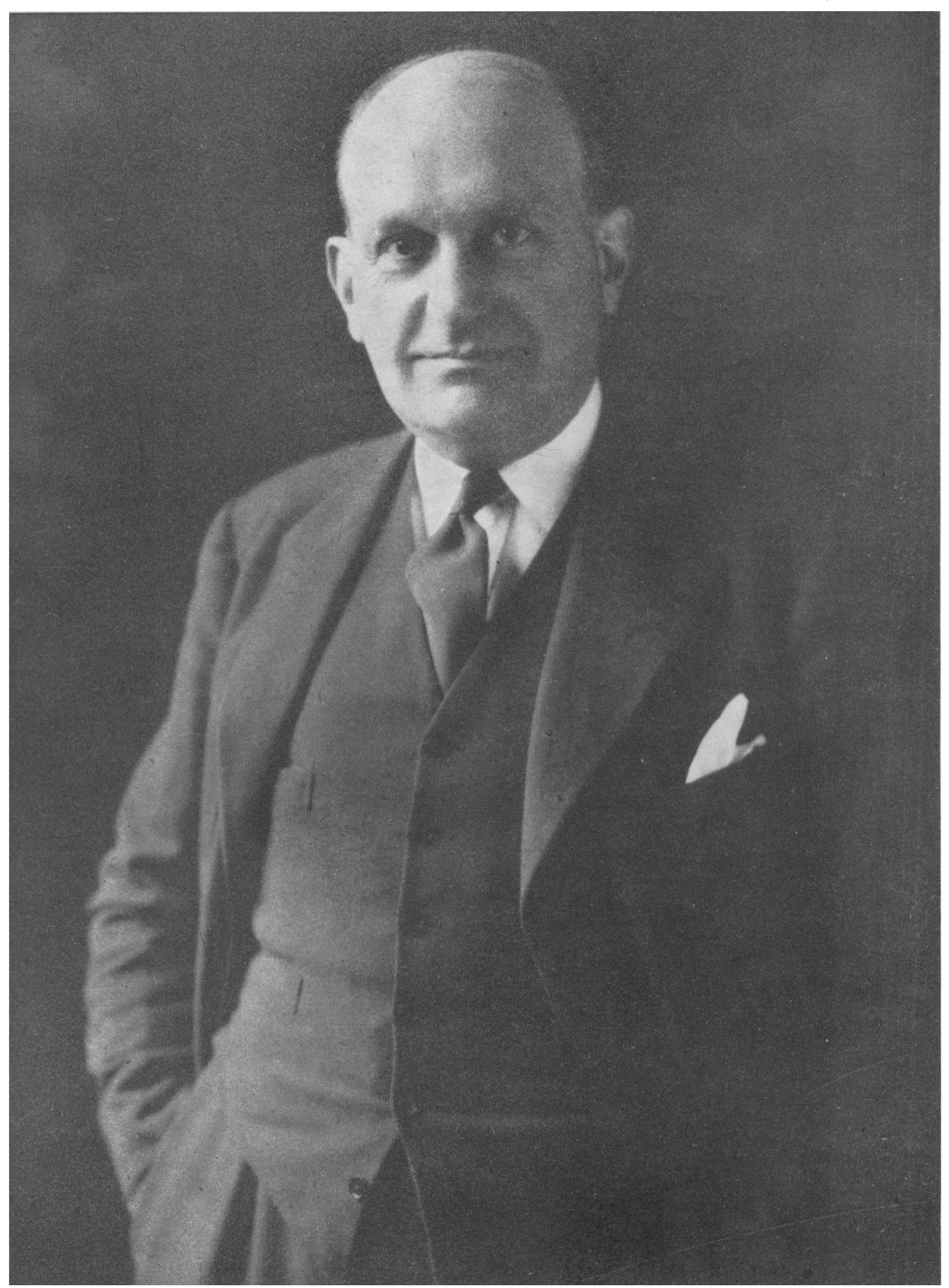

SIR FREDERICK HANDLEY PAGE, C.B.E., F.R.Ae.S. 


\section{A Message from the President}

CN THE LONG HISTORY of the world there have been periods of high adventure, periods when pioneers went forth boldly to explore the unknown world of the spirit and of the material which lay around them.

Most of those who then lived were unaware of the pioneers' work going on in their midst, were unaware even of the pioneers whose names would be for ever linked with their times. The difficulties and dangers a like of travel and the lack of communication. prevented anything but a narrow diffusion of the knowledge of current events.

Few people in the world to-day, with the knowledge contributed by broadcasting, by press and by post, can fail to be conscious of the fact that they are living in an historical period, the like of which the world has not yet seen. Because of that consciousness of their destiny each and every one must be held responsible for the part they will be called on to play in these next fateful years.

I believe that the more personal contacts are cultivated, the less is the danger of misunderstanding among men. Such contacts are now at hand with the increasing facilities for cheap and rapid travel.

I believe no less that it is to the air to which we must look for that world-wide ease of fast travel which alone will enable the peoples of the world to get together.

And it is with the air and its many problems that the Royal Aeronautical Society is so closely concerned.

Eighty years ago six men met to form this Society, the object of which was, ultimately, to discover that means of swift travel by which world-wide personal contacts could be made. For half of those years, only the spirit of its. belief in its inevitable success kept the Society alive.

It was only thirty-six years ago that the first member of the Society flew in a powerdriven machine. During those thirty-odd years the fire of inspiration of the aircraft pioneers burned brightly. The pioneers were few and the reapers of what they have sown have been many. 


\section{A M ESSA G FROM THE PRESIDENT}

There is always the danger that the spirit of progress may be lost in the desire for immediate material gain, and it is a danger against which this great Society must always be on its guard.

The long history of the Royal Aeronautical Society has not failed to show that pioneering spirit of progress which has made its name honoured throughout the world. I cannot emphasize too strongly the hope that during the next 80 years the Society will not lose that spirit which comes from striving towards that perfection which ever eludes one in realization. The spirit of the Society, its progress and its reputation, depend-as do those of a nation-on its individual members.

It is a well-established engineering maxim that you cannot get more work out of a machine than you put into it. Members owe as much to the Society as it does to them. The spirit of its members is not measured by the material gain they get from their subscription, nor is the power of the Society to be measured by the count of its members.

I am not going to refer here to the history of the Society in detail. That history has recently been written, and I hope that every member will obtain a copy and gain from it that inspiration which will enable them to make the history of the next eighty years worth the writing. The members of the Society, indeed, are" now writing the very first page of the history of the Air Age. And every member cannot help being concerned with what will appear upon that page.

There is much to be done by us all in the next few years, and the goodwill, knowledge, and experience of all members must be called upon. Only by every member working in the spirit which has made the Society great, will it go forward and retain that authority of which it may well be proud.

In the words of Carlyle, " Properly thou hast no other knowledge but what thou hast got by working; the rest is yet all a hypothesis of knowledge; a thing to be argued in all schools, a thing floating in the clouds, in endless logic-vortices, till we try it and fix it. Doubt, of whatever kind, can be ended by action alone."

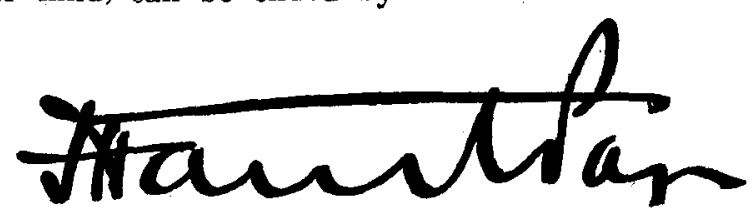

